\title{
Influence of School-based Management Committees (SBMCs) on the Administration of Secondary Schools in Zaria Education Zone of Kaduna State, Nigeria
}

\author{
${ }^{*}$ Prof. B. A. Maina ${ }^{1}$ and Dr A. M. Jumare ${ }^{2}$ \\ ${ }^{1}$ Department of Educational Foundations and Curriculum, Ahmadu Bello University, Zaria, Nigeria. \\ ${ }^{2}$ Institute of Education, Ahmadu Bello University, Zaria, Nigeria.
}

\begin{abstract}
The study is titled "Influence of School-based Management Committees (SBMCs) on the Administration of Secondary Schools in Zaria Education Zone of Kaduna State, Nigeria". Seven objectives were set to guide the study. In line with the objectives, seven research questions and seven hypotheses were asked and formulated, respectively. Samples of 16 Principals, 139 Teachers and 10 officials of Ministry of Education were drawn from the population of selected Secondary Schools in urban and rural areas. One-way analysis of variance (ANOVA) and Scheffe test were used to test the seven Hypotheses. One of hypotheses were retained while 2 rejected. The study revealed some useful findings among which are: decision making process in most Secondary Schools in Zaria Education Zone was enhanced with the rational decisions arrived at; school-community relationship was enhanced with the members of the local community participating in activities such as sporting activities, cultural activities and sharing of water facilities; On the basis of the findings, conclusions were made which include the school-based management committees in most Secondary Schools in Zaria Education Zone, Kaduna State, Nigeria did not provide good standard Football Field, Basketball Court, Badminton Court, Table Tennis, Field for track events, Baseball Field, Mini Animal Park and Shopping Area. On the basis of the findings and conclusions, recommendations were made which include: the school-based management committees are to be enlightened on the need to provide games and recreational facilities, which invariably could enhance students' performance. This is necessary because the facilities could be used for the sake of mental development. This depicts the common adage which says "all work without play, makes Jack a dull boy".
\end{abstract}

Keywords: school-based management committee, administration, Secondary Schools.

\section{Introduction}

It is generally believed that education has the efficacy to enhance development of every sector of nation's economy. This is possible through educational provision, practice and administration, which has to undergo transformations on continuous process. The transformations are necessary in the school system to ensure inclusion and effective 


\section{$3^{\text {rd }}$ World Conference on Research in} TEACHING and EDUCATION

\section{3-25 April, 2021 Prague, Czech Republic}

participation in decision making process. Inclusion refers to a practice which entails the commitment to education as the responsibility of all. It enhances the capacity of Education system through the participation of relevant stakeholders in decision making in schools and communities where they belong. According to Ajuwon (2017), inclusive participation leads to better understanding of problems thereby resulting into better decisions and easier implementation of the decisions.

Inclusive participation is the result of committee system which is seen by Obayan (2018) as a vital ingredient for effective administration of educational institutions where through collaborative effort, Administrators, Educators and other stakeholders are given the opportunity to deal with the complex educational issues as a group. It is considered as a domecratic method of school management, which according to Cotton (2016) allows employees, particularly teachers, adequate participation in any decisions that affect them through committee system and contribute significantly to principal's effectiveness.

Participation and committee system are what formed the basis for School-based Management Committees, which is a process to ensure inclusive and effective participation in management of school system by the relevant stakeholders. According to Caldwell (2015) and Ayeni \& Ibukun (2017), school-based management committee is the process of decentralization of power and authority from government to significant stakeholders to perform statutory responsibilities in the administration, monitoring, evaluation and review of educational policies to ensure effective teaching and learning among others for improved learning outcomes. To Amamchukwu and Oloelube (2016), school-based management committee is management framework which is school-based, student-centered and qualityfocused. When School-based management committee is practised, there is devolution of responsibilities where schools are provided with enhanced flexibility and autonomy to manage their own operation and resources for the development purposes.

School-based Management Committee is established to contribute toward the development of school. In Zaria Education Zone, Secondary School Administration is enhanced through the contributions of School-based Management Committees. The contributions center on decision making process, school-community relationship, students' enrolment and retention, staff development programmes, provision of instructional facilities, provision of teaching and nonteaching staff and provision of games and recreational facilities.

\subsection{Statement of the Problem}

The conditions of Secondary Schools in Nigeria need to be researched well. The conditions deter schools to achieve their main objectives. This is so because Secondary Schools in Nigeria are affected by problems such as poor decision-making process, poor students' enrolment and retention, poor staff development programmes, inadequate instructional facilities, shortage of teaching and non-teaching staff and shortage of games and recreational facilities. Those poor conditions are concurred in Grauwe (2015), Mulayasa (2017), Gamage \& Sooksomchitra (2017) and Bandur (2018).

A functional School-based management committee, in each secondary school in Zaria Education Zone with a clearly defined roles and responsibilities could assist in providing high performance and improved learning outcomes. However, researches in the last few years revealed variety of barriers and challenges for the school-based management committees to 
influence positively on the administration of Secondary Schools for better learning outcome. This informs the decision of the researchers to carry out this research to ascertain the influence of school-based management committees on the administration of Secondary Schools in Zaria Education Zone, Kaduna State, Nigeria.

\subsection{Objectives of the Study}

The study was set to:

1. determine the influence of school-based management committees on decision-making process in Secondary Schools in Zaria Education Zone, Kaduna State, Nigeria;

2. ascertain the influence of school-based management committees on school-community relationship in Secondary Schools in Zaria Education Zone, Kaduna State, Nigeria;

3. find out the influence of school-based management committees on students' enrolment and retention in Secondary Schools in Zaria Education Zone, Kaduna State, Nigeria;

4. assess the influence of school-based management committees on staff development programmes in Secondary Schools in Zaria Education Zone, Kaduna State, Nigeria;

5. examine the influence of school-based management committees on provision of instructional facilities in Secondary Schools in Zaria Education Zone, Kaduna State, Nigeria;

6. The study was said to find out the influence of school-based management committees on provision of teaching and non-teaching staff in Secondary Schools in Zaria Education Zone, Kaduna State, Nigeria; and

7. The study was said to determine the influence of school-based management committees on provision of games and recreational facilities in Secondary Schools in Zaria Education Zone, Kaduna State, Nigeria.

\subsection{Research Questions}

The research asked the following questions:

1. What is the influence of school-based management committees on decision-making process in Secondary Schools in Zaria Education Zone, Kaduna State, Nigeria?

2. do school-based management committees influence school-community relationship in Secondary Schools in Zaria Education Zone, Kaduna State, Nigeria?

3. How do school-based management committees influence students' enrolment and retention in Secondary Schools in Zaria Education Zone, Kaduna State, Nigeria?

4. What is the influence of school-based management committees on staff development programmes in Secondary Schools in Zaria Education Zone, Kaduna State, Nigeria?

5. do school-based management committees influence the provision of instructional facilities in Secondary Schools in Zaria Education Zone, Kaduna State, Nigeria?

6. How do school-based management committees influence provision of teaching and nonteaching staff in Secondary Schools in Zaria Education Zone, Kaduna State, Nigeria?

7. What is the influence of school-based management committees on provision of games and recreational facilities in Secondary Schools in Zaria Education Zone, Kaduna State, Nigeria?

\subsection{Hypotheses}

The following hypotheses were formulated and tested: 


\section{$3^{\text {rd }}$ World Conference on Research in TEACHING and EDUCATION}

1. There is no significant difference in the opinions of Principals, Teachers and officials of the Ministry of Education on the influence of school-based management committee on decision making process in Secondary Schools in Zaria Education Zone, Kaduna State, Nigeria.

2. There is no significant difference in the opinions of Principals, Teachers and officials of the Ministry of Education on the influence of school-based management committees on school-community relationship in Secondary Schools in Zaria Education Zone, Kaduna State, Nigeria.

3. There is no significant difference in the opinions of Principals, Teachers and officials of the Ministry of Education on the influence of school-based management committees on students' enrolment and retention in Secondary Schools in Zaria Education Zone, Kaduna State, Nigeria

4. There is no significant difference in the opinions of Principals, Teachers and officials of the Ministry of Education on the influence of school-based management committees on staff development programmes in Secondary Schools in Zaria Education Zone, Kaduna State, Nigeria.

5. There is no significant difference in the opinions of Principals, Teachers and officials of the Ministry of Education on the influence of school-based management committees on the provision of instructional facilities in Secondary Schools in Zaria Education Zone, Kaduna State, Nigeria.

6. There is no significant difference in the opinions of Principals, Teachers and officials of the Ministry of Education on the influence of school-based management committees on the provision of teaching and non-teaching staff in Secondary Schools in Zaria Education Zone, Kaduna State, Nigeria.

7. There is no significant difference in the opinions of Principals, Teachers and officials of the Ministry of Education on the influence of school-based management committees on the provision of games and recreational facilities in Secondary Schools in Zaria Education Zone, Kaduna State, Nigeria.

\section{Research Methodology}

The researchers used survey research method with the samples of 16 Principals, 139 Teachers and 10 officials of Ministry of Education in selected urban and rural Secondary Schools in Zaria Education Zone. One-way Analysis of Variance (ANOVA) at 0.05 level of significance, was used to test the 7 formulated hypotheses. Where significant differences existed, Scheffe test was employed to ascertain the extent of the differences.

\section{Hypotheses Testing}

One-way Analysis of Variance (ANOVA) at 0.05 level of significance was used to test the 7 formulated null hypotheses. Where significant differences exist, Scheffe test was employed to ascertain the extent of the differences. 


\section{$3^{\text {rd }}$ World Conference on Research in TEACHING and EDUCATION}

Hypothesis 1: There is no significant difference in the opinions of respondents on the Influence of School-Based Management Committees (SBMCs) on decision making process in Secondary Schools in Zaria Education Zone of Nigeria.

To test the hypotheses, responses of all respondents were collected, analysed and presented in a table. Table 1 gives the details.

Table 1: Summary of Analysis of Variance (ANOVA) on Influence of School-Based

Management Committees (SBMCs) on Decision Making Process in Secondary Schools in Zaria Education Zone of Nigeria

\begin{tabular}{lllllllll}
\hline $\begin{array}{l}\text { Source } \\
\text { Variation }\end{array}$ & of & $\begin{array}{l}\text { Sum of } \\
\text { Square }\end{array}$ & Df & $\begin{array}{l}\text { Mean of } \\
\text { Square }\end{array}$ & F-cal & F-critical & P-value & Decision \\
\hline Between Groups & 49.371 & 2 & 24.685 & & & $\mathrm{H}_{1}$ \\
& & & & 2.808 & .071 & Retained
\end{tabular}

3.436

Within Groups $\quad 127.211 \quad 162 \quad .785$

\begin{tabular}{llll}
\hline Total & $\mathbf{1 1 8 0 . 2 6 4}$ & $\mathbf{1 6 4}$ & Ho is Retention if the p-value $>0.05$ \\
\hline
\end{tabular}

Source: Fieldwork, 2020

In Table 1, the computed probability is .071, which is higher than the alpha value of 0.05 set for this study. In other words, the F value of 2.808 is less than the f-critical value of 3.436 while the calculated P-value of .071 is greater than the 0.05 level of significance. Therefore, the null hypothesis $\left(\mathrm{Ho}_{1}\right)$ was retained. It could be concluded that there were no significant differences in the opinions of principals, teachers and Ministry of Education officials in respect of the influence of School-Based Management Committees (SBMCs) on decision making process in Secondary Schools in Zaria Education Zone of Nigeria. The above result corresponds with the results of the research question 1 in which the majority of the respondents agreed with the items stated in the questionnaire where they agreed that through School-Based Management Committees (SBMCs), decision making process in most Secondary Schools in Zaria Education Zone was enhanced with the rational decisions arrived at.

Hypothesis 2: There is no significant difference in the opinions of respondents on the Influence of School-Based Management Committees (SBMCs) on school-community relationship in Secondary Schools in Zaria Education Zone of Nigeria. 


\section{$3^{\text {rd }}$ World Conference on Research in TEACHING and EDUCATION}

To test the hypotheses, responses of all respondents were collected, analyzed and presented in a table. Table 2 gives the details.

Table 2: Summary of Analysis of Variance (ANOVA) on Influence of School-Based

Management Committees (SBMCs) on School- Community Relationship in Secondary Schools in Zaria Education Zone of Nigeria

\begin{tabular}{|c|c|c|c|c|c|c|c|}
\hline $\begin{array}{l}\text { Source of } \\
\text { Variation }\end{array}$ & $\begin{array}{l}\text { Sum of } \\
\text { Square }\end{array}$ & Df & $\begin{array}{l}\text { Mean of } \\
\text { Square }\end{array}$ & F-cal & F-critical & P-value & Decision \\
\hline \multirow[t]{3}{*}{ Between Groups } & 11.349 & 2 & 5.674 & & & & $\mathrm{HO}_{2}$ \\
\hline & & & & 3.1 & & .065 & Retained \\
\hline & & & & 08 & 5.563 & & \\
\hline
\end{tabular}

Within Groups $\quad 165.233 \quad 162 \quad 1.020$

\begin{tabular}{llll}
\hline Total & $\mathbf{1 7 6 . 5 8 2}$ & $\mathbf{1 6 4}$ & Ho is Retention if the $\mathrm{p}$-value $>0.05$
\end{tabular}

Source: Fieldwork, 2020

In Table 2 , the computed probability is .065 , which is higher than the alpha value of 0.05 set for this study. In other words, the F value of 3.108 is less than the f-critical value of 5.563 while the calculated P-value of .065 is greater than the 0.05 level of significance. Therefore, the null hypothesis $\left(\mathrm{Ho}_{2}\right)$ was retained. It could be concluded that there were no significant differences in the opinions of principals, teachers and ministry of education officials in respect of the influence of School-Based Management Committees (SBMCs) on school-community relationship in Secondary Schools in Zaria Education Zone of Nigeria. The above result corresponds with the results of the research question 2 in which the majority of the respondents agreed with the items stated in the questionnaire where respondents in most Secondary Schools agreed that through School-Based Management Committees (SBMCs) school-community relationship was enhanced with the members of the local community participate in school activities such as sporting activities, cultural activities and sharing of water facilities of the school.

Hypothesis 3: There is no significant difference in the opinions of respondents on the Influence of School-Based Management Committees (SBMCs) on students' enrolment and retention in Secondary Schools in Zaria Education Zone of Nigeria. 
To test the hypotheses, responses of all respondents were collected, analyzed and presented in a table. Table 3 gives the details.

Table 3: Summary of Analysis of Variance (ANOVA) on Influence of School-Based

Management Committees (SBMCs) on Students' Enrolment and Retention in Secondary Schools in Zaria Education Zone of Nigeria

\begin{tabular}{llllllll}
\hline $\begin{array}{l}\text { Source of } \\
\text { Variation }\end{array}$ & $\begin{array}{l}\text { Sum of } \\
\text { Square }\end{array}$ & Df & $\begin{array}{l}\text { Mean of } \\
\text { Square }\end{array}$ & F-cal & F-critical & P-value & Decision \\
\hline Between Groups & 13.037 & 2 & 6.518 & & & & $\mathrm{H}_{3}$ \\
& & & & 8.973 & .002 & Rejected
\end{tabular}

Within Groups $\quad 163.545 \quad 162 \quad 1.010$

\begin{tabular}{llll}
\hline Total & $\mathbf{1 7 6 . 5 8 2}$ & $\mathbf{1 6 4}$ & Ho is Rejection if the $\mathrm{p}$-value $<0.05$ \\
\hline
\end{tabular}

Source: Fieldwork, 2020

In Table 3, the computed probability is .002 , which is lower than the alpha value of 0.05 set for this study. In other words, the F value of 38.973 is greater than the f-critical value of 6.457 while the calculated P-value of .002 is lower than the 0.05 level of significance. Therefore, the null hypothesis $\left(\mathrm{Ho}_{3}\right)$ was rejected. This means that significant difference existed among principals, teachers and ministry of education officials in their perception on the influence of School-Based Management Committees (SBMCs) on students' enrolment and retention in Secondary Schools in Zaria Education Zone of Nigeria. The above result corresponds with the results of the research question 3 in which the majority of the respondents disagreed with the items stated in the questionnaire. To ascertain the extent of differences, Scheffe test was employed. Details are presented in Table 4.

Table 4: Scheffe Multiple Comparison Statistics Test among the Principals, Teachers and Ministry of Education Officials in Respect to Influence of School-Based Management Committees (SBMCs) on Students' Enrolment and Retention in Secondary Schools in Zaria Education Zone of Nigeria
(I) Status
(J) status
Mean difference $(\mathbf{I}-\mathbf{j})$
Std.
Error
Sig. 


\section{$3^{\text {rd }}$ World Conference on Research in TEACHING and EDUCATION}

\begin{tabular}{llccc}
\hline Principals & Teachers & -.325 & .232 & .378 \\
& Principals & $4.689^{*}$ & .198 & .002 \\
MOE officials & MOE & $4.325^{*}$ & .232 & .002 \\
& Teachers & -.364 & .193 & .171 \\
Teachers & Teachers & $5.129 *$ & .198 & .002 \\
& Principals & .364 & .193 & .171 \\
\hline
\end{tabular}

*The mean deference is significant of the 0.05 level.

It is evident from the post-Hoc test that difference existed in the opinions of the three groups of respondents on the influence of School-Based Management Committees (SBMCs) on students' enrolment and retention in Secondary Schools in Zaria Education Zone of Nigeria. Details of the multiple comparison post-Hoc test as indicated by Table 4, the mean score of principals 4.689 was found to be closer to that of MOE officials 4.325, implying that the difference between the two groups were not significant. However, the mean score of teachers 5.129 was found to be higher than that of principals and MOE. This implies that the teachers differ significantly in their opinions on influence of School-Based Management Committees (SBMCs) on students' enrolment and retention in Secondary Schools in Zaria Education Zone of Nigeria. This by implication means through School-Based Management Committees (SBMCs), students' enrolment and retention were enhanced. This was as a result of supervision, mobilization, sensitization, and regular meetings between SBMC officials and parents.

Hypothesis 4: There is no significant difference in the opinions of respondents on the Influence of School-Based Management Committees (SBMCs) on staff development in Secondary Schools in Zaria Education Zone of Nigeria.

To test the hypotheses, responses of all respondents were collected, analyzed and presented in a table. Table 5 gives the details.

Table 5: Summary of Analysis of Variance (ANOVA) on Influence of School-Based Management Committees (SBMCs) on Staff Development in Secondary Schools in Zaria Education Zone of Nigeria

\begin{tabular}{lllllll}
\hline $\begin{array}{l}\text { Source } \\
\text { Variation }\end{array}$ & of & $\begin{array}{l}\text { Sum of } \\
\text { Square }\end{array}$ & $\begin{array}{l}\text { Mean of } \\
\text { Square }\end{array}$ & F-cal & F-critical & P-value Decision \\
\hline
\end{tabular}




\section{$3^{\text {rd }}$ World Conference on Research in TEACHING and EDUCATION}

23-25 April, 2021

Prague, Czech Republic

$\mathrm{HO}_{4}$

\section{.078 Retained}

6.720

Within Groups $\quad 126.364 \quad 162 \quad .904$

\begin{tabular}{llll}
\hline Total & $\mathbf{1 5 6 . 5 7 7}$ & $\mathbf{1 6 4}$ & Ho is Retention if the $\mathrm{p}$-value $>0.05$ \\
\hline
\end{tabular}

Source: Fieldwork, 2020

In Table 5, the computed probability is .078, which is higher than the alpha value of 0.05 set for this study. In other words, the F value of 2.816 is less than the f-critical value of 6.720 while the calculated P-value of .078 is greater than the 0.05 level of significance. Therefore, the null hypothesis $\left(\mathrm{Ho}_{4}\right)$ was retained. It could be concluded that there were no significant differences in the opinions of principals, teachers and ministry of education officials in respect of the influence of School-Based Management Committees (SBMCs) on staff development in Secondary Schools in Zaria Education Zone of Nigeria. The above result corresponds with the results of the research question 4 in which the majority of the respondents agreed with the items stated in the questionnaire. This means the respondents agreed that both teaching and nonteaching staff were allowed to go for in-service training, conferences, workshops, seminars and symposia through efforts of SBMCs in most Secondary Schools .

Hypothesis 5: There is no significant difference in the opinions of respondents on the Influence of School-Based Management Committees (SBMCs) on provision of instructional facilities in Secondary Schools in Zaria Education Zone of Nigeria.

To test the hypotheses, responses of all respondents were collected, analyzed and presented in a table. Details are presented in Table 6 gives the details. 


\section{$3^{\text {rd }}$ World Conference on Research in TEACHING and EDUCATION}

Table 6: Summary of Analysis of Variance (ANOVA) on Influence of School-Based Management Committees (SBMCs) on Provision of Instructional Facilities in Secondary Schools in Zaria Education Zone of Nigeria

\begin{tabular}{llllllll}
\hline $\begin{array}{l}\text { Source of } \\
\text { Variation }\end{array}$ & $\begin{array}{l}\text { Sum of } \\
\text { Square }\end{array}$ & Df & $\begin{array}{l}\text { Mean of } \\
\text { Square }\end{array}$ & F-cal & F-critical & P-value & Decision \\
\hline Between Groups & 6.381 & 2 & 3.191 & & & H05 \\
& 170.201 & 162 & 1.051 & & & \\
& & & & & & \\
Within Groups & 17.037 & & \\
\hline Total & $\mathbf{1 7 6 . 5 8 2}$ & $\mathbf{1 6 4}$ & & Ho is Retention if the p-value > 0.05 \\
\hline
\end{tabular}

Source: Fieldwork, 2020

In Table, the computed probability is .059 higher than the alpha value of 0.05 set for this study. In other words, the F value of 1.193, which is less than the f-critical value of 3.037 while the calculated P-value of .059 is greater than the 0.05 level of significance. Therefore, the null hypothesis $\left(\mathrm{Ho}_{5}\right)$ was retained. It could be concluded that there were no significant differences in the opinions of principals, teachers and ministry of education officials in respect of the influence of School-Based Management Committees (SBMCs) on provision of instructional facilities in Secondary Schools in Zaria Education Zone of Nigeria. The above result corresponds with the results of the research question 5 in which the majority of the respondents agreed with the items stated in the questionnaire. This means that the 3 categories of respondent are in agreement that through the efforts of SBMCs, most Secondary Schools in Zaria Education Zone were provided with textbooks, classrooms, chairs, chalkboards, computers, projectors, teaching aid, library facilities, workshops and stationaries.

Hypothesis 6: There is no significant difference in the opinions of respondents on the Influence of School-Based Management Committees (SBMCs) on provision of teaching and non-teaching staff in Secondary Schools in Zaria Education Zone of Nigeria.

To test the hypotheses, responses of all respondents were collected, analyzed and presented in a table. Details are presented in Table 7. 


\section{$3^{\text {rd }}$ World Conference on Research in TEACHING and EDUCATION}

Table 7: Summary of Analysis of Variance (ANOVA) on Influence of School-Based

Management Committees (SBMCs) on Provision of Teaching and Non-Teaching Staff in Secondary Schools in Zaria Education Zone of Nigeria

\begin{tabular}{llllllll}
\hline $\begin{array}{l}\text { Source of } \\
\text { Variation }\end{array}$ & $\begin{array}{l}\text { Sum of } \\
\text { Square }\end{array}$ & Df & $\begin{array}{l}\text { Mean of } \\
\text { Square }\end{array}$ & F-cal & F-critical & P-value & Decision \\
\hline Between Groups & 9.423 & 2 & 4.712 & & & H0 \\
& & & & 3.502 & .079 & Retained \\
Within Groups & 167.159 & 162 & 1.032 & & & \\
\hline Total & $\mathbf{1 7 6 . 5 8 2}$ & $\mathbf{1 6 4}$ & & Ho is Retention if the p-value $>0.05$ \\
\hline
\end{tabular}

Source: Fieldwork, 2020

In Table 7, the computed probability is .079, which is higher than the alpha value of 0.05 set for this study. In other words, the F value of 3.502 is less than the f-critical value of 4.566 while the calculated P-value of .079 is greater than the 0.05 level of significance. Therefore, the null hypothesis ( $\left.\mathrm{Ho}_{6}\right)$ was retained. It could be concluded that there were no significant differences in the opinions of principals, teachers and ministry of education officials in respect of the influence of School-Based Management Committees (SBMCs) on provision of teaching and non-teaching staff in Secondary Schools in Zaria Education Zone of Nigeria. The above result corresponds with the results of the research question 6 in which the majority of the respondents agreed with the items stated in questionnaire. This by implication means, the 3 categories of respondents are in agreement that through the efforts of SBMCs, adequate English teachers, Mathematics, Science, Islamic Studies, Social Studies, Art teachers, Laboratory technicians, library staff and workshop attendants were provided in most Secondary Schools in Zaria Education of Nigeria.

Hypothesis 7: There is no significant difference in the opinions of respondents on the Influence of School-Based Management Committees (SBMCs) on games and recreational facilities in Secondary Schools in Zaria Education Zone of Nigeria.

To test the hypotheses, responses of all respondents were collected, analyzed and presented in a table. Table 8 presents the details. 


\section{$3^{\text {rd }}$ World Conference on Research in TEACHING and EDUCATION}

Table 8: Summary of Analysis of Variance (ANOVA) on Influence of School-Based Management Committees (SBMCs) on Games and Recreational Facilities in Secondary Schools in Zaria Education Zone of Nigeria

\begin{tabular}{llllllll}
\hline $\begin{array}{l}\text { Source of } \\
\text { Variation }\end{array}$ & $\begin{array}{l}\text { Sum of } \\
\text { Square }\end{array}$ & Df & $\begin{array}{l}\text { Mean of } \\
\text { Square }\end{array}$ & F-cal & F-critical & P-value & Decision \\
\hline Between Groups & 4.811 & 2 & 2.408 & & & H0 \\
& & & & 5.174 & & Rejected \\
& 179.767 & 162 & 1.060 & & & \\
Within Groups & & & & & & \\
\hline Total & $\mathbf{1 8 3 . 5 7 8}$ & $\mathbf{1 6 4}$ & & Ho is Rejection if the p-value $<0.05$ \\
\hline
\end{tabular}

Source: Fieldwork, 2020

In Table 8 , the computed probability is .002 , which is lower than the alpha value of 0.05 set for this study. In other words, the F value of 5.174 is greater than the f-critical value of 2.271 while the calculated P-value of .001 is lower than the 0.05 level of significance. Therefore, the null hypothesis $\left(\mathrm{Ho}_{7}\right)$ was rejected. This means that significant difference existed among principals, teachers and ministry of education officials in their perception on the influence of School-Based Management Committees (SBMCs) on games and recreational facilities in Secondary Schools in Zaria Education Zone of Nigeria. The above result corresponds with the results of the research question 7 in which the majority of the respondents disagreed with the items stated in the research questionnaire. To ascertain the extent of differences, Scheffe test was employed. 


\section{$3^{\text {rd }}$ World Conference on Research in TEACHING and EDUCATION}

Table 9: Scheffe Multiple Comparison Statistics Test among the Principals, Teachers and Ministry of Education Officials in Respect of Influence of School-Based Management Committees (SBMCs) on Games and Recreational Facilities in Secondary Schools in Zaria Education Zone of Nigeria

\begin{tabular}{llccc}
\hline (I) Status & $(\mathbf{J})$ status & $\begin{array}{c}\text { Mean } \\
\text { difference }(\mathbf{I}-\mathbf{j})\end{array}$ & $\begin{array}{l}\text { Std. } \\
\text { Error }\end{array}$ & Sig. \\
\hline Principals & Teachers & -.1252 & .331 & .218 \\
& Principals & $22.180^{*}$ & .196 & .001 \\
MOE officials & MOE & $23.903^{*}$ & .334 & .003 \\
& Teachers & -.1672 & .162 & .191 \\
Teachers & Teachers & $15.258^{*}$ & .198 & .001 \\
& Principals & .1342 & .193 & .191 \\
\hline
\end{tabular}

*The mean deference is significant of the 0.05 level.

It is evident from the post-Hoc test that difference existed in the opinions of the three groups of respondents on the influence of School-Based Management Committees (SBMCs) on games and recreational facilities in Secondary Schools in Zaria Education Zone of Nigeria. Details of the multiple comparison post-Hoc test was indicated in Table 9, the mean score of principals 22.180 was found to be closer to that of MOE 22.903, implying that the difference between the two respondents was not significant. However, the mean score of teachers 15.258 was found to be lower than that of principals and MOE officials. This implies that the teachers differ significantly in their opinions on influence of School-Based Management Committees (SBMCs) on games and recreational facilities in Secondary Schools in Zaria Education Zone of Nigeria. From the differences of opinion of teachers and principals/MOE officials, it could be concluded that SBMCs in most Secondary Schools in Zaria Education Zone did not provide good standard football field, basketball court, badminton court, table tennis, field for track events, baseball field, mini animal park and shopping area. 


\section{$3^{\text {rd }}$ World Conference on Research in TEACHING and EDUCATION}

\section{Summary of Major Findings}

The study revealed that through School-Based Management Committees (SBMCs):

1. decision making process in most Secondary Schools in Zaria Education Zone was enhanced with the rational decisions arrived at;

2. school-community relationship was enhanced with the members of the local community participating in activities such as sporting activities, cultural activities and sharing of water facilities;

3. students' enrolment and retention were enhanced as a result of supervision, mobilization, sensitization, and regular meetings between SBMC officials and parents;

4. both teaching and non-teaching staff were allowed to go for in-service training, conferences, workshops, seminars and symposia;

5. most Secondary Schools in Zaria Education Zone were provided with textbooks, classrooms, chairs, chalkboards, computers, projectors, teaching aids, library facilities, workshops and stationaries;

6. there was adequate provision of English, Mathematics, Science, Islamic Studies, Social Studies, Art, teachers, Laboratory technicians, library staff and workshop attendants in most Secondary Schools in Zaria Education of Nigeria; and

7. SBMCs did not make influence in the provision of good standard Football Field, Basketball Court, Badminton Court, Table Tennis, Field for track events, Baseball Field, Mini Animal Park and Shopping Area.

\section{Conclusions}

On the basis of the findings, the study concludes that through the school-based management committees, decision making process, school-community relationship, students' enrolment and retention, teaching and non-teaching staff were enhanced. Also, textbooks, classrooms, chairs, chalkboards, computers, projectors, teaching aids, library facilities, workshops and stationaries were provided. Similarly, English, Mathematics, Science, Islamic Studies, Social Studies, Art teachers, Laboratory technicians, library staff and workshop attendants in most Secondary Schools in Zaria Education Zone were provided though the SBMCs. However, the school-based management committees in most Secondary Schools in Zaria Education Zone, Kaduna State, Nigeria did not provide good standard Football Field, Basketball Court, Badminton Court, Table Tennis, Field for track events, Baseball Field, Mini Animal Park and Shopping Area.

\section{Recommendations}

On the basis of findings and conclusions, it is hereby recommended that:

1. The managers of secondary education and other stakeholders in Zaria Education Zone are to ensure the sustainability of contributions of school-based management committees on decision making process, school-community relationship, students' enrolment and retention, staff development programmes, 


\section{$3^{\text {rd }}$ World Conference on Research in TEACHING and EDUCATION}

provision of instructional facilities, provision of teaching and non-teaching staff and provision of games and recreational facilities for better performance of the system; and

2. The school-based management committees are to be enlightened on the need for the provision of games and recreational facilities, which invariably could enhance students' performance. This is necessary because the facilities could be used for the sake of mental development. This depicts the common adage which says "all work without play, makes Jack a dull boy".

\section{References}

Ajuwon, P. (2017). Making Inclusive Education Work in NIgeri: Evaluation of special Educators Attitudes. Disabilities Studies Quarterly, Vol. 3(2).

Amamchukwu, R. N. \& Oluelube, N. P. (2016). Management of school plant for effective service delivery inpublic schools in Rivers State of Nigeria. Human Resource Management Research 5(4), 95-102.

Ayeni, A. I. \& Ibokun, W. O. (2017). A conceptual model for school-based management operations and quality assurance in Nigerian Secondary Schools . Journal of Education and learning 2(2), 36-43.

Bandur, A. (2018). A study of the implementation of school-based Management in flores primary schools in Indonesia. (PhD) University of Newcastle. Retrieved from http://www.newcastle.edu.au

Caldwell, B. J. (2015). School-based management. UNESCO International Institute for Educational Planning (IIEP). Education Policy Series.

Cotton, J. L. (2016). Participation's effect on Performance and Satisfaction. New York: Saga Publishers.

Gamage, A. \& Sooksomchitra, B. (2017). Assessment of school-community relationship in Sokoto State Secondary Schools : The Role of School-Based Management Committee. A paper presented at the $2^{\text {nd }}$ National Conference organized by National Institute for Educational Planning and Administration.

Grauwe, S. O. (2015). "Influence of School Management Committees Motivational Practice on Kenya Certificate of Primary Education Performance", in public primary schools of Suba-west Division, Migori District Kenya. Retrieved from http://www.ncst.go.ke

Mulayasa, D. (2017). Primary school pupil's perception of the efficacy of mother tongue Education in Ibadan Metropolis. Asia Social Science, 7, (12), 72-78.

Obayan, P. (2018). Revitalization Education in African. Ibadan: Stirling Publishers. 